\title{
PENGARUH LAJU ALIR DALAM PROSES PENGEMASAN KOLOM KROMATOGRAFI PENUKAR ION
}

\section{EFFECT FLOW RATE IN THE PACKING PROCESS OF COLUMN ON ION EXCHANGE CHROMATOGRAPHY}

\author{
Vino Soaduon Hamonangan Simanjuntak, \\ Fakultas Farmasi, Universitas Pancasila, Jagakarsa, Depok, Indonesia, \\ Corresponding Author : vinosoaduon@,rocketmail.com
}

\begin{abstract}
Resin separose (one of them DEAE (Diethylaminetil) Fast Flow is a resin widely used in ion exchange chromatography. In the resin packaging process in the column, recommended flow rate on minimal column height that is $15 \mathrm{~cm}$. In the process of packing the columns with different amounts and column height from the recommendations, a different optimum flow rate is required. It is necessary to determine the optimum flow rate in the packaging process of Separose resin on glass glass column (SAC 100/500 mm. In this research, the flow rate is varied with values above and below of the recommended flow rate. The results showed that the optimum flow rate is $150 \mathrm{~mL} / \mathrm{min}$ which gives the asymmetry value of 1.8 and the value of HETP 0.0035 .
\end{abstract}

Keywords: ion exchange chromatography; flow rate; DEAE separose fast flow resin

\section{PENDAHULUAN}

Metode kromatografi adalah salah satu teknik pemurnian yang banyak dilakukan dalam proses analisa kimia dan produksi karena sifatnya yang selektif. Pada proses produksi biasanya kromatografi digunakan untuk proses pemurnian. Pemurnian secara kromatografi dilakukan dengan cara memanfaatkan perbedaan sifat fisika-kimia umum dari bentuk molekul atau ion, ukuran partikel, kelarutan dan lain-lain (Haddad, 1997). Kromatografi adalah proses pemisahan zat terlarut berdasarkan perbedaan migrasi suatu sistem yang terdiri dari fasa diam dan fasa gerak. Salah satu fase gerak yang sering dipakai adalah molekul yang memiliki perbedaan mobilitas sehingga terjadi perbedaan dalam adsorpsi, partisi, kelarutan, tekanan uap, ukuran molekul, atau kerapatan muatan ion. Perbedaan cara kerja kromatografi itu memberikan variasi teknik seperti kromatografi penukar ion (ion exchange chromatography), kromatografi eksklusi ukuran (size exclusion chromatography), kromatografi fasa normal (phase normal chromatography), kromatografi fasa terbalik (reverse phase chromatography), kromatografi afinitas (affinity chromatography) (Hagelet al., 2008).

Kromatografi penukar ion (ion exchange chromatography) sering digunakan dalam proses pemurnian yang hanya diterapkan pada senyawa ionik, metode ini banyak digunakan dalam memisahkan molekul protein terutama enzim. (GE Healthcare.Sepharose, 2017). Perbedaan selektif antara fase diam (resin) dengan senyawa target serta senyawa yang tidak kita inginkan (untargeted), maka masing-masing komponen akan bergerak sepanjang kolom (fase diam) dengan laju alir yang tergantung pada penyerapan karakteristik dalam kolom. Pada proses pemisahan ada beberapa senyawa yang akan keluar dari kolom dengan interval waktu yang berbeda, karena proses keseluruhannya adalah migrasi yang dihasilkan oleh tenaga pendorong selektif dari fase gerak. Proses penahanan dan pelepasan senyawa kimia dalam proses kromatografi salah satunya adalah karena bentuk dan struktur kolom terkemas (column packing) atau resin terkemas (resin packing). Beberapa teknik pengemasan kolom kromatografi dapat dibedakan berdasarkan parameter yang tergantung pada karakteristik resin yang digunakan. Setiap resin memiliki liganda, basa, atau senyawa kimia yang spesifik sebagai matriks resin. Proses pengemasan kolom akan berpengaruh terhadap efisiensi kolom. Salah satu parameter yang berpengaruh adalah laju aliran linier (linier flow rate). Dimana nilai laju aliran linier suatu resin memiliki batas interval dari tinggi kolom yang digunakan (Ishihara et al., 2007). Tujuan penelitian ini adalah untuk mengetahui pengaruh laju alir terhadap efisiensi 
kolom, sehingga dapat mengkonfirmasi nilai laju alir optimum yang digunakan dalam proses pengemasan kolom. Banyak instruksi atau cara kerja dari distributor (vendor) resin tidak menyebutkan secara detail jumlah resin yang harus digunakan untuk mencapai laju alir dalam proses packing kolom. Jadi pengujian optimal nilai laju alir diperlukan untuk menghasilkan kolom packing yang baik (Gavara et al, 2015).

Setiap resin memberikan nilai laju aliran linier. Salah satu contohnya adalah resin $D E A E$ Separose Fast Flow mempunyai nilai konstan laju alir 300-400 cm/jam dengan minimal bed height $15 \mathrm{~cm}$. Tetapi pada industri atau penelitian lain tidak memerlukan jumlah resin yang banyak untuk mencapai ketinggian bed height yang telah diinstruksikan. Hal ini dikarenakan jumlah resin yang ada dalam penelitinan atau industri tersebut sudah cukup memisahkan sampel. Sehingga penelitian ini akan mengamati pengaruh laju alir dalam proses pengemasan kolom dengan ketinggian kurang dari $15 \mathrm{~cm}$, dan hasil pengemasan kolom dapat diukur dengan uji efisiensi kolom. Hasil kromatogram yang dihasilkan ditentukan nilai asimetri, dengan nilai $1 \sim 1,8$ dari kromatogram dan didukung dari perhitungan HETP (GE Healthcare.Sepharose, 2017).

\section{METODE PENELITIAN Bahan}

Bahan-bahan yang digunakan dalam penelitian ini adalah etanol $20 \%, \mathrm{NaCl} 0,4 \mathrm{M}$ dalam air (larutan bufer), $0,8 \mathrm{M} \mathrm{NaCl}$ dalam air (larutan sampel), akuades, resin DEAE Sepharose Fast Flow.

\section{Alat}

Alat-alat yang digunakan adalah AKTA pilot sistem (GE AKTA PILOT), kolom SAC 100/50 mm (Lisure Science), 196,25 mL (GE company), Stick silika.

\section{Prosedur Penelitian}

\section{Metode pengemasan kolom.}

Metode pengemasan kolom haruslah ditentukan terlebih dahulu terkait laju alir optimum yang digunakan untuk kolom, jenis resin, dan kuantitas dari resin. Setelah diperoleh jumlah resin sesuai dengan tinggi kolom yang diinginkan, lalu dilanjutkan dengan proses penghomogenan resin dengan etanol 20\%. Resin yang sudah dihomogenkan, dimasukkan secara perlahan dalam kolom hingga mencapai tinggi kolom yang diinginkan.

\section{Pemilihan sampel.}

Bahan untuk pelarut kolom yang paling tepat adalah pelarut yang akan digunakan untuk proses kromatografi pada kolom tersebut, tapi hal ini bukanlah yang praktis atau ekonomis. Sebagai alternatif, dapat menggunakan eluen $\mathrm{NaCl}$ atau aseton. Pelarut ini dapat digunakan untuk memberikan indikasi yang baik untuk kualitas packing kolom. Hasil elusi dipantau dengan mengukur nilai konduktivitas yang menghasilkan kromatogram dan juga digunakan untuk menghitung nilai HETP. Keuntungan menggunakan larutan $\mathrm{NaCl}$ adalah karena banyak tersedia dan dapat digunakan dengan aman untuk pengujian semua kolom.

\section{Evaluasi kolom.}

Efisiensi kolom tergantung pada seberapa baik proses pengemasan kolom. Proses pengemasan kolom yang tidak baik menimbulkan aliran yang tidak merata saat proses kromatografi dan memberikan hasil yang dapat mengurangi zona resolusi. Metode yang menggunakan senyawa berwarna, seperti dextran biru harus dihindari karena tidak memenuhi kriteria dan tidak dapat digunakan dengan media pertukaran ion dan kromatografi afinitas. Uji efisiensi pada kolom dapat dilihat dengan nilai HETP dan faktor $A s$ (asimetri puncak) dengan nilai 1,8-2. Nilai ini dapat ditentukan dengan mudah pada kromatogram yang diperoleh.

\section{Penghitungan HETP.}

Volume sampel harus sekitar $1 \%$ dari total bagian dasar resin dengan konsentrasi 1,0\% (v/v) $\mathrm{NaCl}$. Kemudian dihitung nilai HETP dari konduktivitas kurva. Jika nilai HETP lebih besar akan memberikan nilai lempeng teoritis yang baik dalam proses pemisahan. Nilai HETP dapat ditentukan dengan menggunakan rumus:

$$
\text { HETP }=\mathbf{L} / \mathbf{N}
$$

$\mathrm{L}=$ Tinggi dasar resin $(\mathrm{cm})$;

$\mathrm{N}=$ Jumlah theoritical plate $(\mathrm{GE}$ Healthcare.BPGs Column efficienc, 2017). 


\section{Skema kerja}

\section{Resin separose}

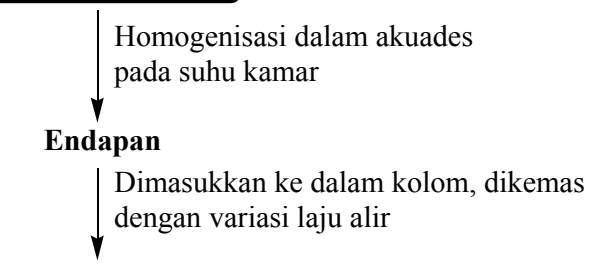

Kemasan kolom

Ekuilibrasi kolom dengan larutan $\mathrm{NaCl} 0,4 \mathrm{M}$ dimasukkan larutan $\mathrm{NaCl} 0,8 \mathrm{M}$

Eluasi dengan larutan $\mathrm{NaCl} 0,4 \mathrm{M}$

Kromatogram

$\downarrow$ Evaluasi hasil

Data

(Nilai asimetri dan HETP)

\section{HASIL DAN PEMBAHASAN}

Kondisi Proses Packing

Sesuai dengan prosedur bahwa resin disimpan di dalam lemari pendingin/ kulkas pada suhu $4-8^{\circ} \mathrm{C}$, maka perlu dikondisikan terlebih dahulu suhu resin untuk sama dengan suhu ruangan $\left(25^{\circ} \mathrm{C}\right)$, dengan cara mengeluarkan resin dari kulkas, dimasukkan ke dalam gelas ukur yang sesuai, didiamkan selama 1 malam (sekaligus berfungsi untuk mengetahui volume atau jumlah resin). Dijaga kelembapan dan suhu ruangan tidak berubah secara drastis selama proses pengendapan dalam adaptasi suhu. Kemudian dihitung prosentase pengendapan resin yang digunakan untuk menentukan jumlah resin pada pengemasan kolom yang diinginkan menggunakan kolom yang ada. Dalam penelitian ini kolom yang digunakan mempunyai diameter $50 \mathrm{~mm}$. Dengan perhitungan

$$
\begin{aligned}
& \text { Volume bed height }=\boldsymbol{\pi} \mathbf{x} \mathbf{r}^{2} \mathbf{x} \mathbf{t}, \\
& \text { dimana: } \\
& \mathrm{r}=\text { jari-jari kolom } \\
& \mathrm{t}=\text { tinggi kolom }
\end{aligned}
$$

Compress factor untuk resin DEAE Sepharose Fast Flow adalah 1,15, berasal dari metode instruksi GE company. Ini merupakan suatu rekomendasi yang diberikan oleh sistem dan resin spesifik yang kebetulan berasal dari perusahaan yang sama, sehingga sudah ada penelitian sebelumnya yang menunjukkan angka compress factor.
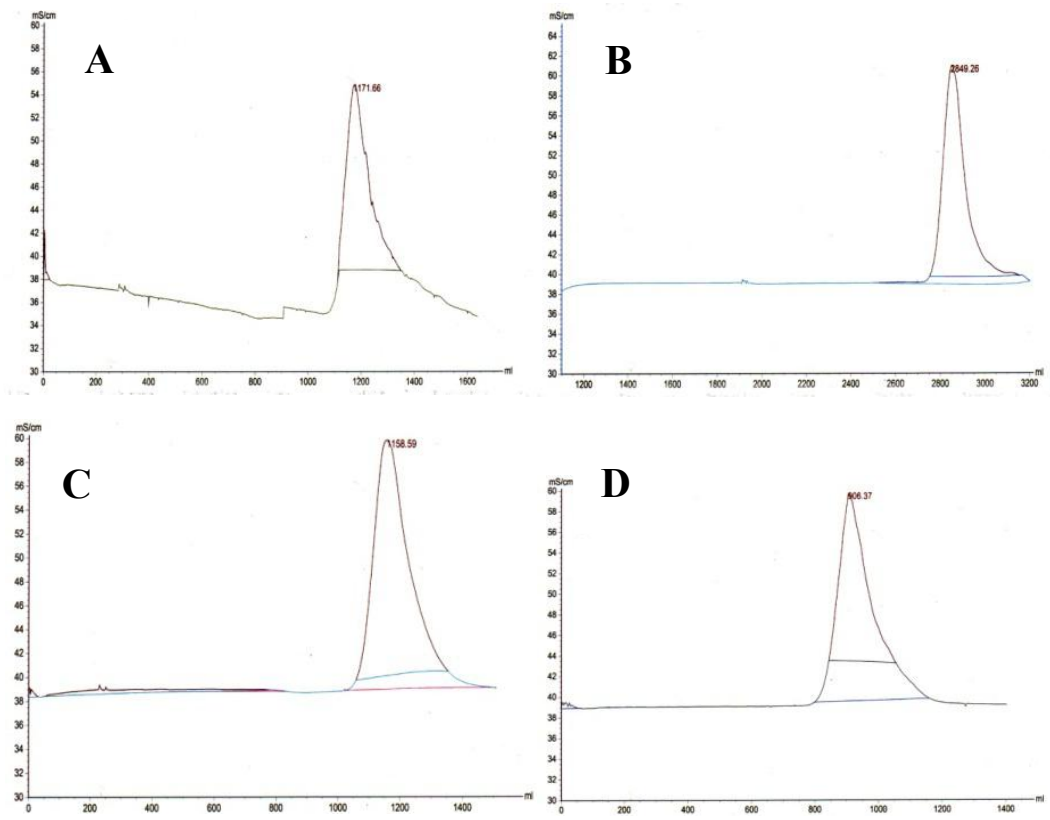

Gambar 1. Kromatogram packing kolom menggunakan laju alir $50 \mathrm{~mL} /$ menit (A), laju alir $100 \mathrm{~mL} / \mathrm{menit}$ (B), laju alir $150 \mathrm{~mL} / \mathrm{menit}$ (C) dan $200 \mathrm{~mL} /$ menit (D).

\section{Kondisi pengemasan kolom}

Pada proses pengemasan kolom dan evaluasi efisiensi kolom, semua proses dilakukan pada suhu ruang $\left(25^{\circ} \mathrm{C}\right)$, hal ini disesuaikan dengan karakteristik resin DEAE Sepharose Fast
Flow. Pada proses pengemasan kolom juga dijaga tidak ada gelembung udara yang terjebak di dalam mesin, net support, ataupun selang, sehingga pada saat proses pengemasan kolom atau proses evaluasi efektifitas kolom tidak 
mempengaruhi performa dari resin pada kolom. Pengaruh lain dalam proses pengemasan kolom juga dimininalisir.
Berikut merupakan hasil evaluasi kolom dengan nilai asimetri kromatografi dengan menggunakan laju alir 50, 100, 150 dan $200 \mathrm{~mL} /$ menit.

\section{Evaluasi kolom dengan asimetri kromatogram}

Tabel 1. Hasil evaluasi kolom dengan asimetri kromatografi

\begin{tabular}{lcccc}
\hline No & $\begin{array}{c}\text { Laju Alir } \\
(\mathbf{m L} / \mathbf{m e n i t})\end{array}$ & $\begin{array}{c}\text { Bed Height } \\
(\mathbf{c m})\end{array}$ & Asimetri & $\begin{array}{c}\text { Memenuhi } \\
\text { syarat }\end{array}$ \\
\hline 1 & 50 & 10.5 & 2,5 & - \\
2 & 100 & 10,5 & 2,1 & - \\
3 & 150 & 10,5 & 1,8 & + \\
4 & 200 & 10,5 & 2,16 & - \\
\hline
\end{tabular}

Hasil ini menunjukkan bahwa hasil proses pengemasan kolom menggunakan laju alir $50, \quad 100$, dan $200 \mathrm{~mL} / \mathrm{menit}$ tidak direkomendasikan untuk jenis resin DEAE Sepharose Fast Flow dengan menggunakan kolom SAC 100/500 mm dengan tinggi resin pada kolom terkemas kurang dari $15 \mathrm{~cm}$. Sedangkan hasil packing kolom dengan kecepatan laju alir $150 \mathrm{~mL} /$ menit didapatkan hasil asimetri dengan nilai 1,8. Hal ini menunjukkan bahwa hasil asimetri kolom lebih baik menggunakan laju alir $150 \mathrm{~mL} /$ menit.

\section{Pengaruh laju alir dalam proses pengemasan kolom \\ Nilai optimal laju alir dalam proses packing kolom yang juga didukung data HETP kolom masing-masing laju alir, dapat dilihat pada Gambar 2.}

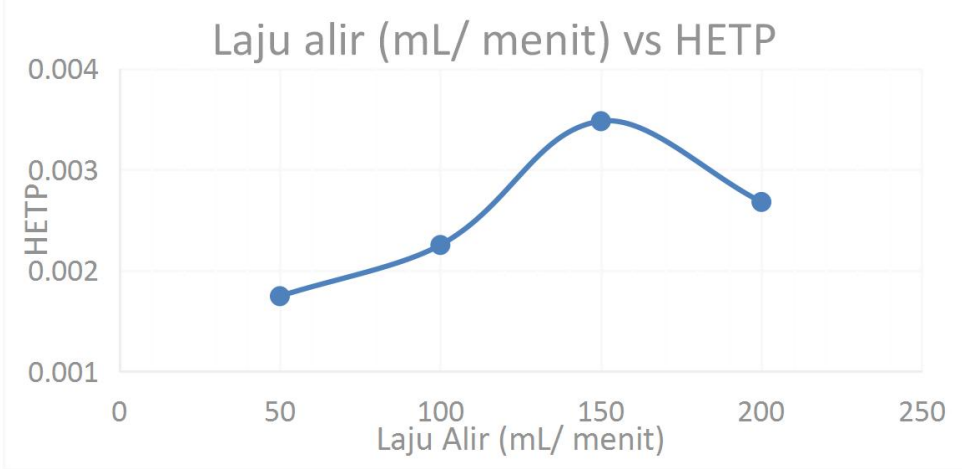

Gambar 2. Grafik plot Laju alir (mL/menit) dengan HETP

Pola grafik (Gambar 2) menunjukkan bahwa jumlah pelat teoritis dalam resin yang sudah dikemas pada kolom dari laju alir yang rendah $(50 \mathrm{~mL} /$ menit $)$ menuju laju alir yang lebih tinggi $(150 \mathrm{~mL} / \mathrm{menit})$ mengalami peningkatan HETP yang linear. Hasil ini terlihat bahwa kenaikan laju alir dalam proses pengemasan kolom memberikan pengaruh yaitu angka lempeng teoritis hasil pengemasan kolom mengalami penurunan jika diberikan laju alir lebih dari $150 \mathrm{~mL} / \mathrm{menit}$. Hasil penelitian ini memperlihatkan peningkatan laju alir juga tidak selalu memberikan HETP yang bertambah terus. Hal ini menunjukkan bahwa ada nilai optimal laju alir dalam proses pengemasan kolom. Pada saat proses proses pengemasan kolom menggunakan laju alir di bawah atau di atas yang direkomendasikan distributor (vendor) untuk setiap masing-masing jenis resin, dapat memberikan hasil yang kurang baik atau kurang optimal. Pada laju alir $150 \mathrm{~mL} /$ menit memberikan hasil asimetri 1,8 dan dengan jumlah pelat teoritis lebih banyak dibandingkan dengan laju alir yang lebih rendah atau lebih tinggi. Hasil capaian grafik pada Gambar 2 laju alir 150 $\mathrm{mL} /$ menit memberikan nilai HETP yang lebih tinggi dari pada menggunakan laju alir yang lainnya, sehingga efisiensi kolom pada packing kolom dengan laju alir $150 \mathrm{~mL} /$ menit 
direkomendasikan untuk jenis resin DEAE Sepharose Fast Flow.

\section{KESIMPULAN}

Proses packing kolom kromatografi biasanya dikembangkan dengan rentang konstan laju alir tertentu. Hasil penelitian ini menunjukkan laju alir optimum $150 \mathrm{~mL} /$ menit adalah laju alir yang optimum untuk jenis resin DEAE Sepharose Fast Flow dengan bed height $10.5 \mathrm{~cm}$.

\section{DAFTAR PUSTAKA}

[1] Dragull K, Beck JJ.2012. Isolation of Natural Products by Ion Exchange Methods. Methods in Molecular Biology vol. 864, p. 189-219

[2] Fritz JJ. 2004. Early milestones in the development of ion-exchange chromatography: a personal account. Journal of Chromatography A,vol. 1039 p. 3-12

[3] Gavara, PR, et. al. 2015. Chromatographic Characterization and Process Performance of Column-Packed Anion Exchange Fibrous Adsorbents for High Throughput and High Capacity Bioseparations. Argentina. Laboratorio de Materiales Biotecnológicos, Depto. de Ciencia y Tecnología, Universidad Nacional de Quilmes-IMBICE (CONICET)

[4] GE Heatlhcare.BPGs Column. 2017. https:/www.gelifesciences.com/gehcls_ima ges/

GELS/Related\%20Content/Files/131472954 5976/litdoc18117070 US 20161013211553. pdf. (access 23 November 2017)

[5] GE Heatlhcare. Column Efficiency testing. 2017. http://www.processdevelopmentforum. com/files/tips/28937207AA1.pdf.(access 23 November 2017)

[6] GE Heatlhcare.Sepharose ${ }^{\mathrm{TM}}$ Fast Flow ion exchange media and prepacked column formats. 2017.

https://www.gelifesciences.com/gehcls_ima ges/GELS/

Related\%20Content/Files/1314742967685/li tdoc18117722_20161014020352.pdf. (access 23 November 2017)

[7] Haddad, PR., P.E. Jackson (Eds.). 1997. Ion Chromatography-Principles and Application, Elsevier, Amsterdam

[8] Hagel LL, Jagschies, G., and Sofer, G. eds. 2008. Handbook of process chromatography: development, manufacturing, validation, and economics, 2nd Edition, Academic Press, London 12 (5) p. 327-329

[9] Ishihara T, Kadoya T, Yamamoto S. 2007. Application of a chromatography model with linear gradient elution experimental data to the rapid sacle-up in ion-exchange process chromatography of proteins. Journal of Chromatography A vol. 1162 p. 34-40

[10] Levison PR. 2003. Large-scale ion exchange column chromatography of proteins Comparison of different formats. Journal of Chromatography B vol. 790 p. 17-33. 